\title{
Fragile states, decentralisation and the nature of barriers to citizen participation in local government: a view from Pakistan
}

\author{
Aijaz Ali $^{1}$ iD
}

Received: 30 October 2020 / Accepted: 15 December 2021 / Published online: 21 January 2022

(c) The Author(s) 2022

\begin{abstract}
The purpose of decentralisation reforms is to narrow the gap between the public and government and increase public participation in decision-making. However, empirical evidence from developing countries suggests otherwise. A case in point is Pakistan, even though it has a well-structured local government system consisting of three levels of government, district, tehsil and union councils. Nevertheless, Pakistan's nascent but fragile democracy and the non-democratic nature of decisionmaking at the state level prevent public participation and as a result do not remove but rather create obstacles to citizens' involvement in service delivery. This paper therefore argues that citizen participation in Pakistan's local government system faces more barriers which are imposed by the centralised state rather than removing hurdles to community participation. I demonstrate that having well-structured local governments is not enough for community engagement instead of a nationstate's strong commitment to pro-community participation. The aim of this study is to identify and examine the barriers to public participation and how they prevent participation in the local government service delivery process, especially when non-democratic countries such as Pakistan introduce local government reforms. A qualitative study was carried out with a questionnaire containing seven open-ended qualitative questions. The thematically analysed results show that the military establishment introduced local government systems which have used local governments to suppress community autonomy and prevent community participation. As there is a patron/client relationship between the central government of Pakistan and the feudal lords and local elites, local elites have indulged in corruption and favouritism which hinder public participation at the grassroots level in the local governments in the province of Sindh, in Pakistan.
\end{abstract}

Keywords Fragile states · Decentralisation - Barriers · Citizen participation $\cdot$ Sindh . Pakistan

Aijaz Ali

aali189@bradford.ac.uk; chandioaijaz@gmail.com

Extended author information available on the last page of the article 


\section{Introduction}

Community participation in policy-making and local government is one of the UN's Sustainable Development Goals (SDGs). Similarly, the relevant literature suggests that decentralisation nurtures a positive relationship between policy-makers and the public and improves accountability (Wengert 1985; Gaynor 2014). During the 1980s, many political leaders in Africa, Asia and Latin America became enthusiastic about devolution reforms in their respective countries (Crook and Manor 1998). Even some non-democratic regimes introduced local government reforms with lofty claims of promoting public participation in decision-making and in the distribution of resources. An example of this was the Devolution Power Plan 2001 introduced by General Musharraf, president of Pakistan after his military coup in 1999.

Local government systems are, however, often introduced into neo-patrimonial contexts where the local political elites often capture these decentralised institutions. A local government system does not necessarily contribute positively to service delivery and community participation. Various local government reforms have therefore been manipulated by distrust of and interference from the central authorities (Clausen 2020; Crook and Manor 1998; Gaynor 2014). As a result, public participation in local government is a controversial issue in many countries (Ishii 2017). Little research has been carried out to determine the nature of these patterns which are sometimes caused by the central authorities not empowering the common citizens (Mohmand and Cheema 2007; Wahid et al. 2017; Rid and Murtaza 2018). This article explores and examines the barriers to citizen participation in the local government system and their impact on service delivery in Pakistan's Sindh province.

\section{Literature review}

\section{Local government and barriers to citizen participation}

This literature review brings together the literature on the role of decentralisation in civic engagement and barriers to public participation in the local policymaking process. Decentralisation is described as the transfer of decision-making and of planning to the state's field organisations, local administrative units, semiautonomous and parastatal organisations or to local governments (Rondinelli et al. 1989). There is a hope that decentralisation can create a robust and active citizenry in which ordinary citizen organisations take responsibility for their own development process. In other words, it can serve as a school of democracy for the common populace by enabling their participation in local development activities (Smith 1985; Wolman 1990; Paul 1987; Rietbergen-McCracken 1996; World Bank 1996; Shah 2006). Even so, it is not realised that many authoritarian regimes introduce decentralisation reforms merely to sustain the central 
government's inwardly exclusive governmentality, which means its methods of managing society and legitimising its authoritarian raison d'être by excluding individuals and groups which have the potential to oppose the will of the dictatorial government (Khan 2015; Heo 2018; Aslam 2019).

These devolution reforms are often introduced as a top-down process with the single motive of ensuring inwardly exclusive governmentality in which the administrative controls are designed and held at the centre. There is ample evidence of contextual cases in which the successive military dictators of Pakistan launched local government reforms with the simple purpose of legitimising their military regimes. For instance, General Ayub Khan, who first imposed martial law in Pakistan and soon afterwards implemented the system of Basic Democracies in 1958, General Zia-ul-Haq, who introduced a local government system in 1979 and General Musharraf, then Chief of Army Staff, who introduced a third round of decentralisation soon after removing the elected government in 1999 (Khan 2015; Aslam 2019). The problem is that if these decentralisation reforms were not introduced with the genuine intention of creating a meaningful democracy, then the local governance inevitably faced a variety of plagues which vitiated the real purpose of increasing public participation and local democratisation (Bates and Bones 2021; Botes and Rensburg 2000; Gaynor 2014). These challenges have ranged from the central state's role remaining over-centralised, elite control over local government power and unequal structures which create many more issues which prevent effective decentralisation.

\section{The inhibiting role of the central government}

As far as top-down decentralisation reforms are concerned, the central authority is the main barrier to meaningful community participation in the process of local government development. The biggest challenge to public participation has been when the central government has introduced a reform as merely a requirement of its funding agencies but these reforms are just window-dressing in reality (Gilbert 1987; Sedgwick 2010; Danquah et al. 2018). Apart from the mere pretence of local democratisation as has consistently been in case of Pakistan (Mohmand and Cheema 2007), there are other issues caused by the lack of any support from the central authority. For instance, the developing local governments experience the flaws in the administrative frameworks, the nation-state is simply perpetuating an inherited colonial legacy, as has been the case in Pakistan (Cheema et al. 2005; Mukherjee 2016), and the state tends to continue to be centralised with its real motives hidden (Botes and Rensburg 2000; Phago and Molosi-France 2018; Kvartiuk and Curtiss 2019). Examples of this have been given by Agrawal and Ribot (1999) who presented a few case studies of decentralisation from South Asia and West Africa, showing that in the countries concerned, Nepal in South Asia and Senegal and Mali in West Africa, central governments maintained the centralised powers even in the devolved system of local governments. The central nature of these governments created distrust among weaker groups of poor citizens in these developing countries. If a central authority's administrative system is full of structural flaws in terms of laws designed simply to benefit the country's elites and officials, then pretended devolution to local 
governments creates elite political clientelism which ultimately leads to segregation between the common citizens and the state (Rafique and Khoo 2018; Mohmand and Cheema 2007; Dauti 2017).

\section{Military and bureaucratic establishments and the plight of public participation}

There is a common assumption that decentralisation reforms are laden with promises of democratisation and of public participation, so the majority of the literature has focused on the impact of local government reforms on democratisation and service delivery. In the context of Pakistan, however, Aslam (2019) found that dictators could use decentralisation reforms to create a new political support class among the local elites in order to legitimise the central military regime. Another purpose of such authoritarian regimes has been to prevent civil society from challenging them and thus ultimately gaining greater support and thereby sustaining their power by creating inwardly exclusive governmentality (Heo 2018). It is possible to see that there is a trend in other dictatorial regimes such as the People's Republic of China, the Democratic Republic of Congo and Rwanda, where decentralisation reforms are implemented in sham and cynical ways (Aslam 2019). The centralised bureaucracies of military regimes rely on such decentralisation reforms (Sedgwick 2010) because the dictatorial rulers know that bureaucracy is the heart of a central state (Botes and Rensburg 2000) and that the national bureaucracy can be used to exploit the meaning and purpose of decentralisation reforms, and consequently the potential civil society becomes divided into the elite class and the poor (Yang and Callahan 2007; Schonwalder 1997; Crook and Manor 1998).

\section{Elite control over local government power and unequal power structures}

Dictators in Pakistan have consistently used local government reforms to bolster their political legitimacy by distributing power among powerful local elites (Mohmand and Cheema 2007; Aslam 2019). In Pakistan, whenever dictatorial regimes have introduced decentralisation reforms, the local elites have acted as a conduit between these military dictators and the ordinary people and as a result the local political clients have contributed to reinforcing the segregation between the ordinary citizens and the state (Aslam 2019; Plessing 2017; Mohmand and Cheema 2007). Because these elites benefit from the distribution of the dictatorial power, they tend to keep hold of their power by exploiting government institutions (Dauti 2017; Wahid et al. 2017; Lima 2019). As a result, citizen participation is either entirely prevented or severely discouraged (Neshkova and Kalesnikaite 2019). For example, the following case studies shed light on how an elite class exploits the decentralisation and the public participation because of unequal power structures. Lima (2019, p. 667) found in Brazil that unequal power structures at the local level and a lack of transparency in government decisions posed the main barriers to citizens' participation and involvement in decision-making. Van den Brandler et al. (2014, p. 502) conducted a case study in Brazil and suggested that the major decisions for local bodies were made outside the newly formed deliberative bodies, and that technocratic 
government departments maintained their authority through their economic superiority and their use of expert knowledge, ultimately inhibiting the influence of underprivileged actors. The tendency towards centralised government and the growth of an elite class and traditional bureaucratic institutions can be difficult to challenge (Analoui 2009; Analoui and Danquah 2017).

\section{Theoretical perspectives}

In this section, several theoretical perspectives are discussed which can be used to interpret the results of this study to show how participation is affected by structural constraints. According to elite theory, power mechanisms are designed to concentrate political power in the hands of a small group of elites (Michels 1915; Khan 2008). These elites might (and usually do) belong to society's upper and middle classes and do not represent the larger community (Bradley 2000; Khan 2008). In such a small group of political elites, the planning system is open to influence from elite tendencies. If such elites dominate the planning system at the local level, marginalised citizens tend to remain disengaged from any political participation (Ananga et al. 2021; Hendriks and Lees-Marshment 2019). Bardhan and Mookherjee (2000) suggested that the lower the governance level, the greater the chance a vested-interest group has to capture the power, and the less protected the state's marginalised citizens will be. Thus, local elites are not interested in interacting directly with disadvantaged communities unless it helps them to create or sustain their false legitimacy or to win votes. There is no opportunity for citizen participation in such contemporary governance environments because local elites operate in closed groups surrounded by tight networks of policy advisors (Hendriks and Lees-Marshment 2019, p. 598).

Botes and Rensburg (2000) commented that citizen participation is constrained at the state level in order to govern society more easily and cheaply and to keep the poor silent in some societies. According to the conspiracy form of participation which Choguill (1996) set out in her theory of the ladder of citizen participation, community participation is constrained to reduce the burden of government responsibility. She provided the following example of such a conspiracy:

In 1975, the Bangladeshi government decided to clear all the cities of squatters and move them to locations peripheral to the city. That process of cleaning up the city was reported in the government-controlled newspapers to inform the literate minority about the 500,000 urban squatters who attended their morning call of nature in the open spaces. The result of these newspaper reports was called an example of informing. (p. 440)

For these governments, poor communities are simply a nuisance. In such cases, the ulterior motives of these elite groups are being served (Botes and Rensburg 2000). In the same vein, Gilbert and Ward (1984) stated that:

Governments often use community participation to legitimise the political system as a form of social control. The level of commitment by many govern- 
ments to community participation has often been dubious or extremely limited. (p. 781)

In such states, the constitution has been shaped from the top down; it has not emerged from the grassroots, and the level of commitment by central governments to community participation has thus been extremely limited (Gilbert and Ward 1984, p. 781). In Pakistan, Lall (2012b) pointed out that the government segregates citizens from their political representatives, which creates a gulf between the state and its public. There is more relevance here because Choguill (1996) stated, in her theory of a ladder of community participation for developing countries, that the majority of underdeveloped countries do not perceive citizen participation as a means of enabling ordinary citizens to influence decisions in projects related to them, but that citizen participation is seen as a means of mutual help among citizens to one another. In her ladder's seventh hierarchy level, she described conspiracy as follows:

Here, no participation in the formal decision-making process is allowed or even considered, as the governments seem to reject any idea of helping the poor. To the government, the poor communities are little more than an embarrassment. It includes cases where the reasons given by authorities for action disguise ulterior motives. (Choguill 1996, p. 439)

Pakistan's local government reforms are a paradox of democratisation without public empowerment with many barriers designed over the years to maintain authoritarian regimes. In reality, however, the central establishment, mainly based on the military and on bureaucracy, has conspired against local government for two ulterior motives: the legitimation of an authoritarian regime, and the desire to secure the co-operation of the local elites in Sindh. First, developing countries tend not to share centralised powers and a seemingly decentralised system and public participation are disguised by authoritarian forces for their own ulterior motives. So if an authoritarian state introduces local government reforms, the local governance merely serves the legitimacy of the central state and segregates ordinary citizens from the government.

In summary, the literature on decentralisation has explored how decentralisation reforms impact on service delivery and on public participation. Nevertheless, the issue of how public participation in decentralisation is affected in dictatorial regimes has not been addressed. This article is an attempt to answer this question by presenting a detailed case study of how Pakistan's successive military dictators have introduced sham local government reforms and have thus created barriers to citizen participation.

\section{The local governments of Pakistan}

Since the inception of Pakistan in 1947, civilian governments have not had the local government system on their agenda (International Crisis Group 2004; Khan and Rehman 2012). The political leadership deliberately did not introduce local government in order to avoid political power being devolved to the local level. Successive military dictators, however, have frequently sought to introduce local government 
systems. For example, General Ayub Khan introduced the Ordinance of Basic Democracies in 1962, followed by General Zia ul-Haq in 1979; and finally, General Musharraf brought in a three-tier district government system in 2001 (Cheema et al. 2005; Taj and Baker 2018).

Musharraf's LGO 2001 was a new three-tiered local government system based on direct and indirect elections. The Union Council Administration represented the lowest tier, the Tahsil/Town Municipal Administration (TMA) represented the middle tier of local government, and the District Government was the highest local government level (Mohmand and Cheema 2007, p. 47). However, the relevant literature shows that the Pakistani military establishment introduced these local governing bodies simply to legitimise their military regimes (Cheema et al. 2005; Abbasi 2006; Mangi et al. 2019; Mohmand and Cheema 2007).

\section{Methodology}

The social constructionist research philosophy informed this qualitative exploratory study. The researcher adopted the constructionist epistemology to enable the respondents to construct reality from their interactions and beliefs based on their experiences with the local government system (2001-2009). Guba and Lincoln (1989) explained that epistemology asks questions such as 'What is the nature of the relationship between the would-be-knower and what can be known?' From a philosophical perspective, constructionism is interested in how human beings interpret and construct the social or psychological world in a specific context (Schwandt 1997). The social constructionist approach suggests that meaningful reality is constructed after its interactions with the mind. All knowledge of reality is not discovered but constructed. Therefore, meaning does not exist in the object; it is not simply waiting to be discovered by someone but is constructed. Crotty (1998) pointed out that objects in the world are indeterminate. They might contain any meaning but meaning takes place when the human mind engages with them. In the current study, it was important for the researcher to conduct a close and detailed reading of the data in order to gain a deeper understanding of what the respondents saw and experienced concerning the barriers to citizen participation. Therefore, in order to remain close to the text, hermeneutic theory was adopted (Neuman 2015). As the questionnaires with qualitative questions were completed in writing, the researcher conducted a series of readings to discover deeper, richer meanings of the answers given to the open-ended questions.

\section{Research design}

An open-ended questionnaire was used to collect the data. The questions were primarily related to the local government system of 2001-2009 which the then president of Pakistan General Pervez Musharraf introduced. The questions covered the following main themes: 
Table 1 Profiles of the respondents

\begin{tabular}{|c|c|c|c|}
\hline District & $\begin{array}{l}\text { Kamber Shahdadkot } \\
\text { No. of participants }\end{array}$ & $\begin{array}{l}\text { Larkana city } \\
\text { No. of participants }\end{array}$ & $\begin{array}{l}\text { Both districts } \\
\text { Total number }\end{array}$ \\
\hline \multicolumn{4}{|l|}{ Age } \\
\hline $18-28$ & 12 & 13 & $25(36 \%)$ \\
\hline $29-38$ & 11 & 10 & $21(30 \%)$ \\
\hline $39-50$ & 12 & 8 & $20(29 \%)$ \\
\hline $51-59$ & 3 & 1 & $4(6 \%)$ \\
\hline $60+$ & 1 & 0 & $1(2 \%)$ \\
\hline \multicolumn{4}{|l|}{ Education } \\
\hline Primary & 6 & 3 & $9(13 \%)$ \\
\hline Secondary & 8 & 3 & $11(16 \%)$ \\
\hline Higher (college) & 11 & 3 & $14(21 \%)$ \\
\hline University & 14 & 21 & $35(51 \%)$ \\
\hline \multicolumn{4}{|l|}{ Profession } \\
\hline Teaching & 6 & 15 & $21(31 \%)$ \\
\hline Councillor/LG & 5 & 3 & $8(11 \%)$ \\
\hline CCB member & 5 & 1 & $6(9 \%)$ \\
\hline Social worker/NGO & 10 & 4 & $14(21 \%)$ \\
\hline Trade union & 3 & 0 & $3(4 \%)$ \\
\hline Shopkeeper & 2 & 1 & $3(4 \%)$ \\
\hline Student & 3 & 3 & $6(9 \%)$ \\
\hline Health & 2 & 0 & $2(3 \%)$ \\
\hline Advocate & 1 & 1 & $2(3 \%)$ \\
\hline Labourer & 1 & 2 & $3(4 \%)$ \\
\hline Revenue & 0 & 2 & $2(3 \%)$ \\
\hline Total & Total: $38(56 \%)$ & Total: $32(46 \%)$ & Total: $70(100 \%)$ \\
\hline
\end{tabular}

(a) Knowledge, experiences and reports of formal programmes of community participation;

(b) Barriers to community participation; and

(c) Known factors in participation.

The questionnaire contained seven open-ended questions with probes to seek the participants' knowledge of, attitude to and practice of citizen participation in the three-tier local government system. Trained field assistants distributed 150 copies of the questionnaire through purposive sampling among former members of CCBs, social workers, teachers, students and government officials (see Table 1). After applying for and receiving ethical approval from the University of Bradford for the data collection, the data collection took place between 19 October 2019 and 26 March 2020. 


\section{Sampling}

Given the study's objectives, a purposive sampling strategy was adopted to recruit participants and carry out data collection. The most important recruitment criterion was to find relevant informants who could give first-hand information concerning the research topic (Neuman 2015). The respondents comprised union councillors $(n=8)$ of whom six were CCB members, teachers $(n=21)$ from different levels, non-profit organisation representatives $(n=14)$, members of trade unions $(n=3)$, local businesspeople $(n=3)$, labourers $(n=3)$, lawyers $(n=2)$, government officials $(n=2)$, healthcare professionals $(n=2)$ and university students $(n=6)$ (see Table 1$)$.

\section{Data collection and field assistants}

For reasons of security, the researcher was not able to travel into the field. Trained field assistants were therefore recruited from two districts: Kamber Shahdadkot (rural) and Larkana (urban) in Sindh province. In many studies, field assistants are gatekeepers and communication mediums between the researcher and the local community (Caretta 2014; Turner 2010). Before the fieldwork, a participant's information sheet, consent form and questionnaire were translated into Sindhi (the local language) and sent to the field assistants. After distributing the information sheet, the field assistants contacted potential participants and those who gave oral or written consent to participate in the study were given the questionnaire. Most of the respondents completed the questionnaire themselves; however, a few needed further explanations, which were promptly provided either by the researcher on the telephone or by the field assistants face-to-face. The field assistants administered 150 questionnaires among the purposively selected sample between October 2019 and March 2020. The field assistants received seventy completed questionnaires which they sent to the researcher through a registered courier service.

\section{Data analysis}

The researcher translated all the interviews into English and had the translations checked by a critical friend to ensure accuracy. The supervisor supervised the entire data analysis process. The author used open coding (Neuman 2015) to conceptualise the statements, assign initial labels and identify various emerging issues from the responses to each research question. To identify or address any recurring issues, for example, consistent sequences of events or anything significant which happened repeatedly, notice had to be taken to make a judgement of possible quality issues (Miles and Huberman 1994; Neuman 2015). Saunders et al. (2019) suggested that identifying themes/issues or categories should be guided by the purpose of the research as expressed in the research questions and objectives. 


\section{Thematic analysis and validity}

Remaining honest during analysis can be challenging for qualitative researchers. For example, when we identify themes without counting them and recording their recurring patterns, we may fall into the trap of bias (Miles and Huberman 1994). In order to avoid such a bias, it is important to keep a record of frequency when something (a) happens sometimes and (b) consistently happens in a specific way (Miles et al. 2014). Thus, qualitative data analysis means searching for patterns in data-significant recurrent themes which respondents emphasise. This is the most accurate way of ensuring analytical honesty (Miles et al. 2014; Neuman 2015).

At the beginning of the first thematic coding stage, there were more emerging issues. An example of how significant recurrent issues were noted is given in Table 2. This table was generated according to related themes in the association between local government and public participation.

Table 2 Method of frequency recording of recurring issues through the first stage of coding

\begin{tabular}{|c|c|c|c|}
\hline SN. & Emerging issues & Frequency & Number of completed questionnaires \\
\hline 1 & $\begin{array}{l}\text { The public kept away from all } \\
\text { activities }\end{array}$ & 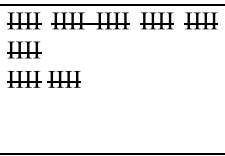 & $\begin{array}{l}1,2,4,8,9,11,12,14,15,17, \\
19,24,26,30,31,20,21,27, \\
44,45,46,47,32,33,35,38,41,42, \\
33,41,48,49,50,51,52,54,55,61,63,64, \\
65,66\end{array}$ \\
\hline 2 & Public as commodity & HII IIII & $1,15,18,33,39,49,51,53,59$ \\
\hline 3 & Public do not know their rights & I & 1 \\
\hline 4 & $\begin{array}{l}\text { Public education is blocked } \\
\text { deliberately }\end{array}$ & ЩI ШII ШI & $\begin{array}{l}1,2,3,5,12,13,15,17,28 \\
21,45,39,35,39\end{array}$ \\
\hline 5 & $\begin{array}{l}\text { Fear that if public become active } \\
\text { it will be trouble for dominant } \\
\text { class }\end{array}$ & Ш世 Ш世 Ш世 I & $\begin{array}{l}1,2,3,8,9,11,19,30,18,45,46,38, \\
48,62,63,64\end{array}$ \\
\hline 6 & $\begin{array}{l}\text { Specific class in power - they are } \\
\text { not from public, } \\
\text { styled to benefit rich }\end{array}$ & 世世 世世 II & $\begin{array}{l}3,17,44,45,46,47,36,51,55,56,57,58 \\
59\end{array}$ \\
\hline 7 & Culture of favouritism & 世世 III & $3,11,13,15,19,27,53,56$ \\
\hline 8 & Corruption & 世 Щ世 Щ世 世 I & $\begin{array}{l}4,5,6,8,9,13,15,17,29,30 \\
31,20,44,45,46,39,40,42,43,48\end{array}$ \\
\hline 9 & $\begin{array}{l}\text { M [Musharraf era 2001-2009] } \\
\text { provided services }\end{array}$ & III & $34,37,34$ \\
\hline 10 & $\begin{array}{l}\text { Musharraf invited public (to some } \\
\text { extent) }\end{array}$ & HI II & $3,4,16,26,22,34,60$ \\
\hline 11 & $\begin{array}{l}\mathrm{Z} \text { [Zardari era } 2013 \text { onwards] } \\
\text { provided services }\end{array}$ & I & 2 \\
\hline 12 & $Z$ - corruption & HII H世 III & $\begin{array}{l}4,5,6,8,10,12,13,19,28,44 \\
34,52\end{array}$ \\
\hline 13 & $\begin{array}{l}\text { The activism of educated } \\
\text { advocates, literary groups, } \\
\text { journalists and social workers }\end{array}$ & 世 I & $10,29,22,38,32,36$ \\
\hline 14 & Poverty & I & 11 \\
\hline 15 & Military has a grip on society & $\mathrm{I}$ & 24 \\
\hline 16 & $\begin{array}{l}\text { State laws, drama, NAB [National } \\
\text { Accountability Bureau] (dead, } \\
\text { fake) }\end{array}$ & I & 44 \\
\hline
\end{tabular}


Table 3 Emerging issues and re-categorisation through the second stage

\begin{tabular}{|c|c|c|c|}
\hline SN. & Emerging issues & Frequency & Number of completed questionnaires \\
\hline 1 & $\begin{array}{l}\text { The public was kept away from } \\
\text { all services to keep them in the } \\
\text { dark }\end{array}$ & 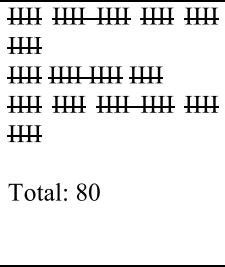 & $\begin{array}{l}1,2,4,8,9,11,12,14,15,17, \\
19,24,26,30,31,20,21,27, \\
44,45,46,47,32,33,35,38,41,42, \\
33,41,48,49,50,51,52,54,55,61,63,64, \\
65,66, \quad 1,15,18,33,39,49,51,53,59 \text {, } \\
1,2,3,5,12,13,15,17,28, \\
21,45,39,35,39, \\
1,2,3,8,9,11,19,30,18,45,46,38, \\
48,62,63,64\end{array}$ \\
\hline \multirow[t]{2}{*}{2} & Corruption & $\begin{array}{l}\text { HII III HI HII HII } \\
\text { H世 IIII }\end{array}$ & $4,5,6,8,9,13,15,17,29,30$ \\
\hline & & Total: 34 & $\begin{array}{l}31,20,44,45,46,39,40,42,43,48, \\
4,5,6,8,10,12,13,19,28,44, \\
34,52\end{array}$ \\
\hline 3 & $\begin{array}{l}\text { Feudal lords, pirs, mirs in all } \\
\text { powers of the state }\end{array}$ & 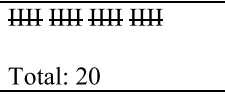 & $\begin{array}{l}3,17,44,45,46,47,36,51,55,56,57,58 \\
59,3,11,13,15,19,27,53,56\end{array}$ \\
\hline 4 & Invited participation & $\begin{array}{l}\text { H II } \\
\text { Total: } 7\end{array}$ & $3,4,16,26,22,34,60$ \\
\hline 5 & Need for public activism & $\begin{array}{l}\text { HII I } \\
\text { Total: } 6\end{array}$ & $10,29,22,38,32,36$ \\
\hline
\end{tabular}

Miles and Huberman (1994) advised that "it is important in qualitative research to know (a) that we are sometimes counting and (b) when it is a good idea to work self-consciously with frequencies" (p. 253); there is good reason for using numbers (frequency) in that researchers can keep themselves analytically honest and protect themselves against bias (Miles et al. 2014). An example is given in Table 3 of how coding was done from the first to the second stage.

Thus, the frequency of the responses was recorded so that the researcher could identify which events of significance recurred (Miles and Huberman 1994; Miles et al. 2014). Finally, in the third stage, these emerging issues were categorised into grand themes (see Table 4).

\section{Findings}

The thematic analysis and frequency records (Miles et al. 2014; Neuman 2015) of participants' detailed stories revealed major themes which described their experiences of the factors responsible for preventing participatory democratic development by the local government authorities of 2001-2009. The findings (see also Table 4) were sub-categorised as follows: (1) alienation caused by the increasing gap between citizens and local authorities (possibly due to psychological reasons for keeping the ordinary masses unempowered in order for them to be exploited); (2) local community participation was discouraged in order to hide illegal uses of available public funds; (3) the local population was not involved with the purpose of giving favour only to local government officials' people and area; and (4) 


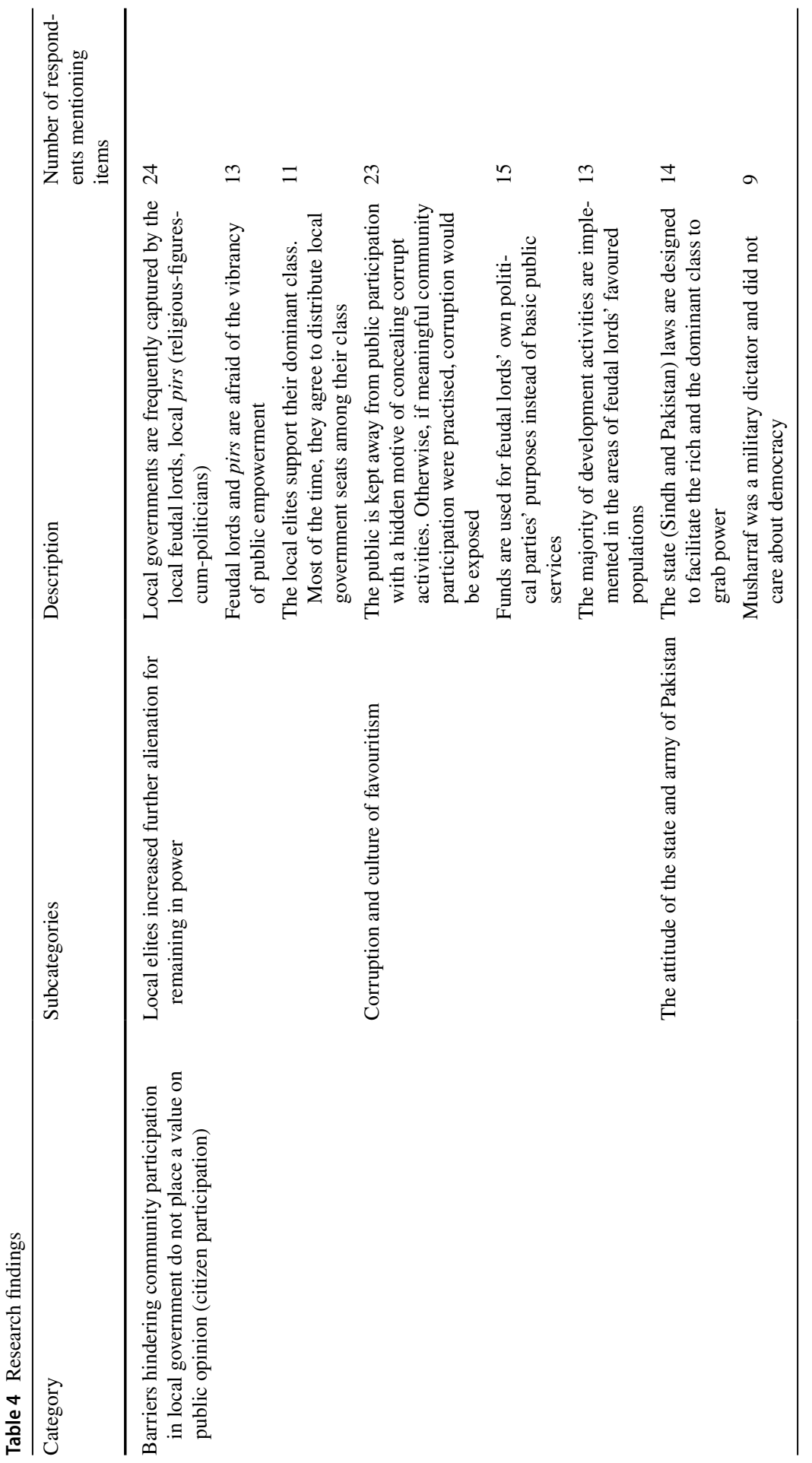

SN Social Sciences

A SPRINGER NATURE journal 
alienation caused by the lack of pro-public participation from the central state of Pakistan. These categorised and sub-categorised results are summarised in Table 4.

\section{Presentation of respondents' voices}

\section{Elite control and alienation: the increasing gap between citizens and local government authorities}

The respondents indicated that the local ruling class avoided community empowerment because they did not want to lose power; they were enjoying themselves. For example, the recorded frequencies of recurring themes show that $68 \%$ of the respondents in this study reported that the class structure (a system of inequalities) was the main obstacle to local community participation in local service delivery. Since the creation of Pakistan, feudal lords and the elite class have been in power in Pakistani politics. The following quotation from one of the respondents depicts how the government protects its own interests instead of those of the poor masses:

They [the powerholders of local government] never let the common people get involved. Their purpose was not to let the common people come close to the elected representatives because if the common people came close to the elected representatives, they would be able to learn about their rights. (Ahmer, male teacher, Larkana)

The ruling class, often referred to as feudal lords, landlords and local elite politicians, has been seen as protecting its own interests against those of the ordinary citizens of Sindh. This powerholder class has been thought of as an anti-marginalised population. The ruling elite is afraid of public empowerment, and citizen participation is seen as community empowerment. And community empowerment is felt as a threat to the status quo when a particular elite class has held local power.

These political elites have full access to power. In contrast, the marginalised masses are afraid of these political elites who often remain in power. Elections are held not on genuine democratic principles but in such a way that the local voters have no other choice but to elect the representatives who claim to wish them well. The following comment makes this clear:

They [local government powerholders] did not involve the public because, in Musharraf's government, there were such cruel classes in power [very harsh words due to despair]. That class has played havoc with democracy. They rule the people with the stick [by force and intimidation]. (Khan, male, social worker, Kamber Shahdadkot)

Khan stated that community participation was not practised because these local government officials came into post through elections which were merely showpieces of democracy. In reality, these feudal lords gather votes based on their power and position. These practices of the authoritarian style of local government officials have 
damaged the true spirit of democracy. For example, the following quote shows that the common citizen is used only as a vote during the elections:

They [local government authorities] distanced local communities from the implementation of local councils' policy-making. This is because the common people are used only for the purpose of elections, nothing else. (Naban, male, self-employed, Kamber Shahdadkot)

It is evident that the local political leadership, which was mainly controlled by a particular powerholder class, did not want the ordinary populace to be involved in local policy-making. Public participation was seen as a process of mass empowerment so the local powerholders did not want the local population to be empowered to challenge the society's current ruling set.

Even elected councils have pressured estranged communities more than was expected. The following comment from one respondent makes this clear:

Through legislation [the Local Government Ordinance 2001], the local government should give fundamental services to the local community, [not] isolate communities from all public services. Even the local councils pushed the people of wards and neighbourhoods back. (Yousuf, male, social worker, Larkana)

The respondents seemed to be aware that it was in the legislation that control over basic services should be given to the local communities. However, these legal documents were merely a showpiece for the world to see and in reality the local authorities held the community at a distance.

It appears that the central government acted as merely a one-time broker between the local political elites and the marginalised electorate of Sindh. In other words, the central authorities had no interest in overseeing how the local government institutions were devolved to the local communities. It was a one-off contract between the local government officials and the state but not between the citizens and the local government authorities. For example, one respondent said that:

They [central government] handed over local councils to these Nawabs [chiefs of a particular Sindhi tribe]. The general population is in the same trouble. They [local power holders] never allowed public participation. (Akbar, male, teacher)

The comments quoted above show that the local government power was handed to the local elites, so feudal lords were able to keep the community in a pitiable condition. This happened only because these local powerholders were aware of the central government's attitude and complete lack of interest in implementing the communityempowering legislation. Therefore, the ordinary citizen knows that there will be no positive change under either a military-controlled government or a civilian one. The following comment makes this clear:

The fact is that any government, either martial law [run by a military dictator] or democratic [civilian governments of Pakistan], is always controlled by feu- 
dal lords. And the lower class is always pushed back. So why would they ask a lower class [to be involved]? (Ihsan, male, social worker)

Ihsan was aware that military and civilian governments are two sides of one coin; both forms of government have the same alienating attitude towards the common citizens of Sindh.

\section{A culture of corruption and problems with public participation}

The results show that $72 \%$ of the respondents reported in their replies to the openended questions that the main reason for the absence of public participation was the motive for the corrupt use of the available budgets in the local government accounts. The majority of the respondents felt that the rampant culture of corruption within the local government institutions prevented the local public from becoming involved in local development activities. The motive behind maintaining their non-participation in local development projects was that in the absence of public participation, local government officers could misuse the funds available to deserving communities. The following comment is a good example of what was a recurring theme:

In this period, the mayors thought it necessary to keep the public away because corruption was difficult to perpetrate otherwise. Further, if they had invited the public [to participate], the public could have gained awareness of their rights and demanded their rights. Instead, they [local government officials] were producing fake bills and perpetuating corruption. Therefore, they would never invite public participation. (Mohammad Osman, former member of local council, Larkana)

Among the respondents, there was a perception that public participation would hinder the misuse of local funds by corrupt local officials. Furthermore, public participation was perceived as the medium of public empowerment, but the local elites were not prepared to let citizens be empowered through the civic engagement mechanism. Public participation was therefore seen as a threat by those bent on the corrupt use of the local government powers. The next extract illustrates this:

The main reason for not implementing community participation law was their [local government mayors'] intentions of perpetuating corruption. Otherwise, it might be difficult for them to act corruptly if they invited neighbourhood residents. (Naveed Khan, college student, Larkana)

A strong association has been shown between the culture of corruption and the prevention of citizens' participation. It appears that if the pervasive corruption within the local government continues, the chances of meaningful citizen participation within the local development process are hardly possible. This means that corruption is a significant challenge to public participation and the empowerment of the local communities. This finding is consistent with the literature, which suggests that alienation occurs between the rulers and the ruled when a conflict of interest exists between individuals and the state (Evans et al. 1985; Clark et al. 2017). 
Moreover, the respondents stated that the local government officials' fear of being exposed was also a barrier to citizen participation in the local development process. According to the participants, if the local powerholders who were involved in corrupt activities within the local government institutions were to invite the intended local beneficiaries to participate, their misuse of local power would be publicly exposed. So civic involvement was blocked due to the fear of being exposed. For example, the following view was expressed by one participant about why public participation was felt as a threat to the corrupt local government powerholders:

According to my knowledge, [the reason for] not involving the public in policy implementation is that if they invited the public, the public would expose them-unmask their corrupt deeds. If they became exposed, they could not perpetuate the corruption. The public gives them votes for their development, and once they become exposed, the public would demand their money from them. (Aslam, university student, Larkana)

Public participation has the potential to expose the unscrupulous use of local government power. Local politicians are therefore afraid that the citizens might know how their legitimate funds are being misused if the local community is invited to take part in the local decision-making process.

\section{A culture of favouritism and the plight of community involvement}

If the central state does not have a strong commitment to implementing democratic, participatory decentralisation reforms, the culture of favouritism presents an obstacle to community participation. In addition, when there is no mechanism of checks and balances, the local elites start to strengthen their own people, areas and supporters. For example, one respondent explained:

They [local government officials] hushed public involvement up deliberately. The local authorities indulged in investing a budget in their selected favourite areas. (Ali Ahmed, non-governmental organisation staff, Kamber Shahdkot)

This comment shows that public participation was deliberately prevented because otherwise, the local government officers would not have been able to redirect development projects and funding to their favoured areas. Mohmand and Cheema (2007, p. 50) suggested that locally elected nazims (mayors) tended to oversupply their own villages at the expense of other localities. If funds are not spent in deserving areas, the following situation arises:

In the Musharraf period (2001-2009), there was no participation ... the local community was crying out for drinking water, but there was no chance that the poor would be helped. (Mohammad Hashim, male social worker, Kamber Shahdadkot)

When there is a culture of favouritism, the major proportion of the available funds goes to a few local elites and those whom they favour. As a result, these powerholders do not want to involve the local communities. This also shows that those local 
authorities knew that they did not have any higher authority to call them to account. For example, the following respondent made this clear:

The main reason for not involving the public is that when the administration does not want to work ... the PPP [the civilian government of Pakistan People's Party] period is the other side of the same coin: once the elections are over, then nobody will contact the voters again. (Sain Dad, male teacher, Larkana)

Sain Dad stated that public participation was not practised because the administrative authorities did not want to involve the local communities. Furthermore, even the PPP civilian government had the same authoritarian attitude towards the marginalised citizens.

\section{Alienation due to the lack of support from the central state}

As discussed earlier in the article, due to lack of public involvement in public services, the citizens felt alienated from the state and from government and manifested this feeling through anger, frustration and hopelessness. Even the founder of the local government reforms and head of the state had no interest in the meaningful implementation of local community participation in local development projects. For example, $32 \%$ of the respondents stated that local government was centralised instead of being devolved to the local populace. The following quotation illustrates how the army had caused alienation between ordinary citizens and the local political elites:

Musharraf ran the government through the power of his uniform [military uniform, which does not respect democracy and citizens' rights]. He never looked at the general public. And he just once earned the loyalties of the local politicians [the clientelist group] - the feudal lords, landlords and Syeds. So they always suppressed the public voice. (Mihran, teacher, Larkana)

Musharraf was the head of state and he introduced the revised local government system in 2001. However, his main interest was to legitimise his 1999 illegal military coup. He was therefore not interested in empowering the local communities of Pakistan but instead preferred to win the loyalty of the local feudal elites to support his military regime. The following quote as a good example of what was a recurring theme:

In this period [2001-2009], a class [feudal lords] came into power in local government, and very particular people were elected [meaning that the people who came into power were already chosen]. So they kept the public away from participation because the local government was occupied by a particular class. (Deedar Ali, former male union councillor, Kamber Shahdadkot)

Musharraf's local government reforms created huge alienation between ordinary citizens and the state because the local feudal politicians were consolidated in their 
power and Musharraf compromised on democratic participation in order to win the loyalty of the new local politicians of Sindh.

The respondents seemed to have no expectation that the military government would empower local communities through democratic, participatory mechanisms. It further appears that although the national government should have supported community participation, this was never its intention. The following quote shows that Musharraf, despite introducing the Devolution of Power Plan in 2001, was not interested in public voices:

Musharraf was a military man. So it is not logical that a military dictator would give importance to public opinion, civic dialogue, through community participation. (Ahmed Nawaz, higher secondary school teacher, Larkana)

If a very ordinary citizen knows that a military dictator cannot be interested in promoting public participation, the local elites know even more that community participation is not a good policy for those ruling Pakistan without a democratic structure. The following quote illustrates this clearly:

As they [local government authorities] never involved the public, we common citizens suffer from not having any roads or other basic facilities. They have given us nothing. There are no opportunities for employment. We cannot go to them because of our poverty-stricken position. (Savera, female, health worker, Kamber Shahdadkot)

As is clear from this comment, ordinary people had no access to amenities. The rich people were getting richer and the poor were becoming poorer. It was because of the attitude of indifference on the part of the central state that there was no system of checks and balances. The following quote makes this evident:

There is no system of audit in this institution. The conditions of the marginalised population are a shambles. The public is always suffering from cruelties and hardships. (Abdullah, male, higher secondary school teacher, Kamber Shadadkot)

Abdullah reported that there was no auditing institution which could check where and how public funds were spent. This shows the absence of any state body which can protect the rights of common citizens. Furthermore, it appears that might is right. For example:

Public participation is possible only when whoever comes into power has the will to serve the public [indicating democratic societies], but they [Sindhi local government authorities] have come with the power of sticks [force and intimidation], so why would they invite the public? The public has the same pains and troubles as it had before. (Huzefa, female, teacher, Larkana)

It can be inferred from these comments that the local elites did not like public participation because it would challenge their comfortable status quo in which they get elected without any competition; they even get votes by spreading fear among the poverty-ridden people of Sindh. The local political elites are benefiting from the 
existence of an illiterate, poverty-stricken and politically unaware public, so they naturally tend to keep the general population in the same conditions. This extends the argument of Lima (2019) that community participation cannot hold an elite power accountable because there is no means of contesting the elite character and influence.

\section{Discussion}

The findings presented above suggest that the law has been reduced to a medium which powerholders use to benefit the country as they see it and not the people of Pakistan. Even the local elected representatives reflect the military attitude towards the marginalised public. Musharraf was a military dictator and was therefore beyond public accountability; unfortunately, when the main architect of local government reform is unaccountable to the citizens, the same cynical attitude is likely to be adopted by the lower institutions. For example, district nazims spent public funds and used their state machinery to promote pro-Musharraf rallies during the April 2002 presidential referendum to support Musharraf's party, the Pakistan Muslim League (Quaid-i-Azam) (PML-Q). Moreover, over the years, local governments have proved to be of significant utility to military regimes in Pakistan which seek to apply divide-and-rule strategies (International Crisis Group 2004; Cheema et al. 2005; Abbasi 2006).

The findings of this study are in line with the theoretical assumption (Gilbert and Ward 1984) that military and civilian governments tend to use different forms of control to undermine and suppress community participation and community empowerment. This is the form of conspiracy theorised in the seventh rung of Choguill's (1996, p. 439) ladder model—community participation-which suggests a level of a conspiracy whereby no participation in formal decision-making is allowed or even considered. Furthermore, the government appears to reject any idea of helping the poor. To the government, marginalised and poor citizens are considered only a potential source of political embarrassment. These theoretical threads seem to fit the findings of this current study, as $72 \%$ of the respondents stated that citizens were kept away from local government service delivery with the goal of not allowing the wider population to become informed about their basic rights. The critical issue appeared to be that the real political power bargain was not between ordinary citizens and the central state, but between the local sardars, nawabs, meers and pirs and the central state. Thus, the ordinary citizens remained out of any part of the contract. The local government authorities put common citizens at a distance and maintained the gap between the ruling elite and the ordinary people. This created a psychological barrier which makes the majority of the downtrodden citizens believe that politics and engagement are a job for only the local influential elite of Sindh.

The literature emphasises that the biggest fault-line in Pakistani society is that which has developed between ordinary citizens and the state (Wilder 2009; Lall $2012 \mathrm{a}, \mathrm{b})$. The purpose of this alienation is to reduce people's clarity of awareness of who is ruling them and who is accountable to them (Lall 2012b). That is why the military government(s) prevented Pakistan from pursuing democratic development; 


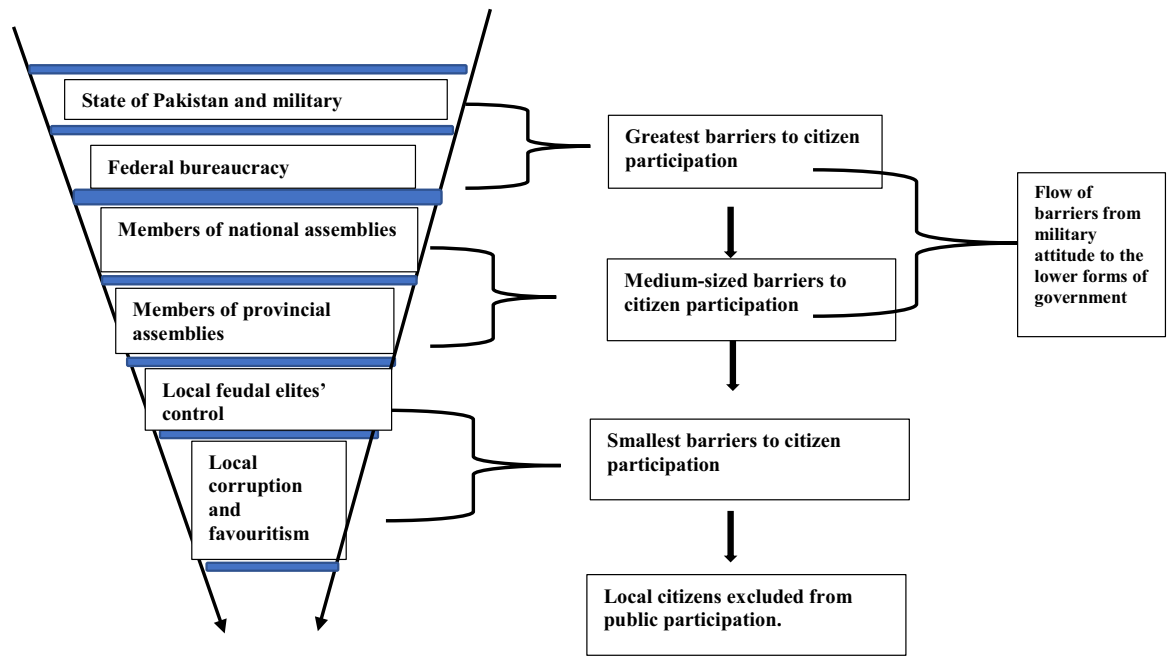

Fig. 1 Conceptual framework based on the findings of this study

even in times of civilian government, the army has continued to rule the country (see Online Appendix A) from the back seat (Talbot 2009; Lall 2012a; Lieven 2012).

The conceptual framework (see Fig. 1) based on the findings of this study illustrates the levels of alienation between the government of Pakistan and the ordinary citizens of Sindh.

Figure 1 illustrates how the attitude of alienation and the interaction gap trickle down from top to bottom. The funnel shape of the model indicates that the level of alienation between citizen engagement and local governance increases at higher governance levels. This ladder model suggests two insights. First, it suggests how the military rules local communities from a distance. The second insight is that although the local governments can encourage public participation, they fail to do so because of the reluctance of Pakistan's central government.

The ladder model of participation explains that the lower governmental institutions inherit the level of non-participation from the top-level government of Pakistan. Thus, alienation between the public and the government becomes stronger in Sindh and throughout Pakistan as the governance level increases. Malesky and Hutchinson (2016, p. 136) pointed out that local participatory democracy, as an opportunity to learn and assimilate democratic values, cannot be achieved unless central governments are willing to permit this democratisation process at the local level.

\section{Strengths and limitations of the study}

This study is one of very few (if any) that have investigated the effect of the fragile state and efforts at decentralisation on public participation in the second largest province of Pakistan. The reasons for this paucity of academic studies are not hard 
to see: (1) a great amount of effort is required to gather empirical data in order to examine in detail the barriers which keep local communities at a distance in local government development programmes; (2) the key strength of this current study is that a very large number (seventy questionnaires with seven open-ended questions) of respondents have provided a very detailed picture of the phenomenon which took place during the supposed local government reform of 2001-2009.

The involvement of only two districts in Sindh, rural and urban, could be a limitation of this study. Furthermore, the fact that circumstances prevented the researcher from being able to be present during the fieldwork could also be a limitation. However, the detailed data on the topic which was obtained from responses to carefully devised open-ended questions has proved to be a good format for a qualitative study in which the respondents could not put their stories in words through their voices in face-to-face conversation.

\section{Conclusion}

The results have produced the central insight that the absence of citizen participation was a deliberate act of alienation. Alienation here means estrangement between local government authorities and ordinary citizens. Psychologically, local communities were put at a distance deliberately. This meant that the already marginalised masses were deliberately pushed back in order to maintain the status quo. First, it could be that the local political elites did not want underdeveloped citizens to have any power. Second, these ruling elites did not want to be accountable to those who have been their servants, election supporters and voters without offering them any development in return. In the case of Pakistan, the attitude of maintaining a big gap between ordinary citizens and the ruling elite was further strengthened by the mindset of the Pakistani army establishment through which local Sindhi feudal lords were deliberately allowed to capture and hold local government power. The local feudal class has also adopted this mind-set of keeping ordinary citizens alienated from public participation in order to maintain their own supremacy. Those ruling the poor members of the general public are not prepared to relinquish their power, influence or privilege. This article has also discussed the role of corruption and the culture of favouritism which have negatively affected public participation in local development projects. This demonstrates that merely introducing local government systems is insufficient when it has the complacent expectation that it will bring citizens closer to the administrative system. The outputs of the local governments must be seen in the context of Pakistan's national government.

Understanding this attitude of government institutions, the main problem is neither the budget deficit nor the monetary policy but the intention of the already established Pakistani institutions: the military and bureaucratic establishment and the feudal class system of Sindh. In terms of implications, this study has explored how the state has established barriers to prevent citizen participation and how these barriers have been strengthened through the very decentralisation framework which should have demolished them. 
Supplementary Information The online version contains supplementary material available at https://doi. org/10.1007/s43545-021-00308-1.

Acknowledgements I want to say thank you to Mat Andrews, Faculty Librarian for Management, Law and Social Sciences, and Health Studies at the University of Bradford, for his encouragement and support during the writing of this research paper. I am also grateful to Nick Sage for his encouragement. I am indebted too to Professor Marie Lall, whose consistent guidance for this paper cannot be forgotten. Finally, I am grateful to Sadiq Bhanbhro, who encouraged me tirelessly to follow this academic path.

Author contributions The author conceived and conducted the study for his doctoral study. The author produced and revised the manuscript. No-one else has contributed to the research or the manuscript.

Funding No organisation funded this research.

Data availability Data are available upon reasonable request. The raw data are available in two formats: raw qualitative data in the native language (Sindhi) and pictures and translated into English in an MS word document.

Code availability Not applicable.

\section{Declarations}

Conflict of interest There is no issue of conflict of interest. I am the only author of this paper and it is drawn from my PhD data.

Ethical approval The appropriate ethical approval was obtained from the Research Ethics Committee at the University of Bradford. The ethical approval reference is E740.

Open Access This article is licensed under a Creative Commons Attribution 4.0 International License, which permits use, sharing, adaptation, distribution and reproduction in any medium or format, as long as you give appropriate credit to the original author(s) and the source, provide a link to the Creative Commons licence, and indicate if changes were made. The images or other third party material in this article are included in the article's Creative Commons licence, unless indicated otherwise in a credit line to the material. If material is not included in the article's Creative Commons licence and your intended use is not permitted by statutory regulation or exceeds the permitted use, you will need to obtain permission directly from the copyright holder. To view a copy of this licence, visit http://creativecommons.org/licen ses/by/4.0/.

\section{References}

Abbasi S (2006) Devolution or de-evolution?: critical study of devolution plan 2000. National Book Foundation, Islamabad

Agrawal A, Ribot J (1999) Making decentralization accountable: a framework for analysis and empirical studies from South Asia and West Africa. J Dev Ar 33(4):473-490

Analoui F (2009) Challenges of successful reform: an international perspective. J Manag Dev 28(6):489-494

Analoui F, Danquah JK (2017) Critical capacity development. Palgrave Macmillan, Cham

Ananga EO, Naiga R, Agong SG, Njoh AJ, Vickers HP (2021) Examining the contribution of community participation in water resource production and management: perspectives from developing countries. SN Soc Sci 1(1):1-20

Aslam G (2019) Decentralization reforms in dictatorial regimes as a survival strategy: evidence from Pakistan. Int Polit Sci Rev 40(1):126-142

Bardhan P, Mookherjee D (2000) Capture and governance at local levels. Am Econ Rev 90(2):135

\section{SN Social Sciences}

A SPRINGER NATURE journal 
Bates J, Bones UOC (2021) Community conversations: deliberative democracy, education provision and divided societies. SN Soc Sci 1(2):1-20

Botes L, Rensburg DV (2000) Community participation in development: nine plagues and twelve commandments. Community Dev J 35(1):41-58

Bradley VJ (2000) Community participation and the village appraisal process in rural England: a case study of Northamptonshire. The University of Leicester

Caretta MA (2014) Situated knowledge in cross-cultural, cross-language research: a collaborative reflexive analysis of researcher, assistant and participant subjectivities

Cheema A, Khwaja AI, Khan A (2005) Decentralization in Pakistan: context, content and causes. Available at SSRN https://ssrn.com/abstract=739712 or https://doi.org/10.2139/ssrn.739712

Choguill MBG (1996) A ladder of community participation for underdeveloped countries. Habitat Int 20(3):431-444

Clausen ML (2020) Decentralization as a strategy of regime maintenance: the case of Yemen. Public Adm Dev 40(2):119-128

Clark WR, Golder M, Golder SN (2017) Principles of comparative politics. CQ Press

Crook RC, Manor J (1998) Democracy and decentralisation in South Asia and West Africa: participation, accountability and performance. Cambridge University Press, Cambridge

Crotty M (1998) The foundations of social research: meaning and perspective in the research process. SAGE, London

Danquah JK, Analoui F, Koomson YED (2018) An evaluation of donor agencies' policies on participatory development: the case of Ghana. Dev Policy Rev 36(S1):O138-O158

Dauti M (2017) The impact of decentralisation on participation in formal organisations in Albania: lessons for community-based interventions. Int Soc Work 60(6):1523-1536

Evans P, Rueschemeyer D, Skocpol T (1985) Bringing the state back in. Cambridge University Press, Cambridge

Gaynor N (2014) Bringing the citizen back in: supporting decentralisation in the fragile states-a view from Burundi. Dev Policy Rev 32(2):203-218

Gilbert A (1987) Forms and effectiveness of community participation in squatter settlements. Reg Dev Dialogue 8(4):56-80

Gilbert A, Ward P (1984) Community action by the urban poor: democratic involvement, community self-help or a means of social control? World Dev 12(8):769-782

Guba EG, Lincoln YS (1989) Fourth generation evaluation. Sage Publications, London

Hendriks CM, Lees-Marshment J (2019) Political leaders and public engagement: the hidden world of informal elite-citizen interaction. Polit Stud 67(3):597-617

Heo I (2018) The paradox of administrative decentralisation reform in young Asian democracies: South Korea and Indonesia. World Aff (Washington) 181(4):372-402

International Crisis Group (2004) Devolution in Pakistan: reform or regression? International Crisis Group, Islamabad, Brussels

Ishii R (2017) Community participation in local governance-an empirical analysis of urbanized local governments in the Philippines and Uganda. Int J Public Adm 40(11):907-917

Khan S (2008) Local governments and local elites. Local Gov Stud 34(4):509-528

Khan SA (2015) Devolution plan 2000: dictatorship, democracy, and the politics of institutional change in Pakistan. Dev Pract 25(4):574-586

Khan MA, Rehman HU (2012) Regional disparities in human capital: the case of Pakistan. Pak Econ Soc Rev 50(1):57-69

Kvartiuk V, Curtiss J (2019) Participatory rural development without participation: insights from Ukraine. J Rural Stud 69:76-86

Lall M (2012a) Citizenship in Pakistan: state, nation and contemporary faultlines. Contemp Polit 18(1):71-86

Lall M (2012b) Why education matters: school 'choice' and differing views on citizenship in Pakistan. Citizsh Stud 16(2):269-286

Lieven A (2012) Pakistan: a hard country. Public Affairs, New York

Lima V (2019) The limits of participatory democracy and the inclusion of social movements in local government. Soc Mov Stud 18(6):667-681

Malesky EJ, Hutchinson FE (2016) Varieties of disappointment: why has decentralisation not delivered on its promises in Southeast Asia? J Southeast Asian Econ 33(2):125-138

Mangi SN, Shah N, Ali Soomro B (2019) A scientific approach to measure public political participation in Pakistan. Asian J Polit Sci 27(1):88-107 
Michels R (1915) Political parties: a sociological study of the oligarchical tendencies of moderndemocracy. https://babel.hathitrust.org/cgi/pt?id=loc.ark:/13960/t4fn1x527\&view=1up\&seq=172

Miles MB, Huberman AM (1994) Qualitative data analysis: an expanded sourcebook, 2nd edn. Sage Publications, London, Thousand Oaks

Miles MB, Saldaña J, Huberman AM (2014) Qualitative data analysis: a methods sourcebook, 3rd edn. SAGE, London

Mohmand SK, Cheema A (2007) Accountability failures and the decentralisation of service delivery in Pakistan. IDS Bull 38(1):45-59

Mukherjee K (2016) Ayub Khan's basic democracy and political continuity in contemporary Pakistan. India Q 72(3):268-277

Neshkova MI, Kalesnikaite V (2019) Corruption and citizen participation in local government: evidence from Latin America. Governance 32(4):677-693

Neuman WL (2015) Social research methods qualitative and quantitative approaches, 7th edn. Pearson, New Dehli

Paul S (1987) Community participation in development projects. World Bank Washington, DC

Phago K, Molosi-France K (2018) Reconfiguring local governance and community participation in South Africa and Botswana. Local Econ 33(7):740-756

Plessing J (2017) Challenging elite understandings of citizen participation in South Africa. Politikon 44(1):73-91

Rafique Z, Khoo SL (2018) Role of community-based organizations (CBOs) in promoting citizen participation: a survey study of local government institutions of Punjab, Pakistan. Int J Sociol Soc Policy 38(3/4):242-258

Rid SA, Murtaza N (2018) The local government system in Sindh: a critical analysis of the Sindh Local Government Act 2013. The Government Research. J Poli Sci 7:33-46

Rietbergen-McCracken J (1996) Participation in practice. The experience of the World Bank and other stakeholders. World Bank, Washington, D.C.

Rondinelli DA, McCullough JS, Johnson RW (1989) Analysing decentralization policies in developing countries: a political-economy framework. Dev Change 20(1):57-87

Saunders MNKP, Lewis P, Thornhill A (2019) Research methods for business students. Pearson Education Limited, Boston

Schonwalder G (1997) New democratic spaces at the grassroots? Popular participation in Latin American local governments. Dev Change 28(4):753-770

Schwandt TA (1997) Qualitative inquiry: a dictionary of terms. Sage, London, Thousand Oaks

Sedgwick M (2010) Measuring Egyptian regime legitimacy. Middle East Critique 19(3):251-267

Shah A (2006) Local governance in developing countries. The World Bank, Washington, D.C.

Smith BC (1985) Decentralization: the territorial dimension of the state. Taylor \& Francis, New York

Taj A, Baker K (2018) Multi-level governance and local government reform in Pakistan. Prog Dev Stud 18(4):267-281

Talbot I (2009) Pakistan: a modern history. Hurst, London

Turner S (2010) Research note: the silenced assistant. Reflections of invisible interpreters and research assistants. Asia Pac View 51(2):206-219

van den Brandler F, Hordijk M, von Schönfeld K, Sydenstricker-Neto J (2014) Decentralization, participation, and deliberation in water governance: a case study of the implications for Guarulhos, Brazil. Environ Urban 26(2):489-504

Wahid A, Ahmad MS, Abu Talib NB, Shah IA, Tahir M, Jan FA, Saleem MQ (2017) Barriers to empowerment: assessment of community-led local development organisations in Pakistan. Renew Sustain Energy Rev 74:1361-1370

Wengert N (1985) Citizen participation: practice in search of a theory. Nat Resour J 25:68

Wilder A (2009) The politics of civil service reform in Pakistan. J Int Aff 63(1):19-37

Wolman H (1990) Decentralization: what it is and why we should care. In: Bennett RJ (ed) Decentralization, local governments and markets: towards a post-welfare agenda, pp 29-42. Oxford, Clarendon Press, England

World Bank (1996) The World Bank participation sourcebook, vol 19. World Bank Publications, Washington, D.C.

Yang K, Callahan K (2007) Citizen involvement efforts and bureaucratic responsiveness: participatory values, stakeholder pressures, and administrative practicality. Public Adm Rev 67(2):249-264 


\section{Authors and Affiliations}

\section{Aijaz Ali ${ }^{1}$}

1 The University of Bradford, Peace Studies and International Development, Richmond Road, Bradford, West Yorkshire, UK 